\title{
Enhancing Supplier Development: An Efficiency Perspective
}

\author{
Hung-Chung Su, Yi-Su Chen, and Ta-Wei (Daniel) Kao
}

University of Michigan-Dearborn

$\mathrm{T}$ his research identifies the factors that contribute to the buyer's efficiency in utilizing supplier development practices for their supplier's performance. Prior studies support the notion that supplier development practices improve supplier performance; however, very few studies focus on the factors that could improve a buyer's supplier development efficiency. Using a survey sample of 261 manufacturing plants from 11 countries, this study shows that relational norms and information sharing affect supplier development efficiency. Furthermore, information sharing by suppliers is more effective than information sharing by buyers in terms of efficiency enhancement.

Keywords: stochastic frontier analysis; supplier development; information sharing; relational norms; alignment method; data envelopment analysis

\section{INTRODUCTION}

Supplier development, a buyer-initiated effort, has been shown to improve supplier performance effectively (Krause 1997; Humphreys et al. 2004; Krause et al. 2007; Modi and Mabert 2007; $\mathrm{Li}$ et al. 2012). However, the efficiency of supplier development tends to vary. For example, a survey finds that the reported reduction in order fulfillment cycle time due to supplier development could vary from $30 \%$ to $80 \% .1$ In addition, the reported reduction in product defects varies even more significantly from $5 \%$ to $90 \%$. This evidence, though anecdotal, suggests that some buyers are more efficient at utilizing their supplier development practices to develop their suppliers than others. That is, some buyers are better at enhancing their supplier development efficiency, which we define as the extent to which a buying firm (i.e., buyer)2 utilizes its supplier development practices (the input) to increase its supplier's performance (the output). This definition is consistent with the broader concept of efficiency, which is generally defined as the extent to which inputs are transformed into output (Green and Mayes 1991). Given that buyers may differ in their efficiency of transforming their supplier development into (improved) supplier performance, to identify interfirm differences in their supplier development efficiency, we follow the same stochastic frontier approach adopted by Lieberman and Dhawan (2005) in which they assess the impact of resources on firm performance using the Battese and Coelli (1995) model (cf. Lieberman and Dhawan 2005). While details about this stochastic frontier approach are discussed later, measuring efficiency with the stochastic frontier approach is superior to the traditional output-input ratio approach. Stochastic frontier explicitly considers firms' heterogeneity across production factors

\section{Corresponding author:}

Hung-Chung Su, College of Business, University of Michigan-Dearborn, 19000 Hubbard Dr., Dearborn, MI 48126, USA; E-mail: hcsu@umich.edu

${ }^{1}$ https://scm.ncsu.edu/scm-articles/article/supplier-developmentstrategies-and-outcomes

"In this study, we use the term "buying firm" and "buyer" interchangeably. Similarly, the term "supplier" in this study refers to a supplying firm.
(Chen et al. 2015) and is capable of estimating both efficiency frontier and a firm's efficiency using cross-sectional data (Lieberman and Dhawan 2005).

We deliberately differentiate between efficiency (doing things right) and effectiveness (doing the right things) in this study. Given that existing studies have documented abundant evidence pertaining to the effectiveness of supplier development practices on improving supplier performance, the premise of this study is that supplier development is effective; that is, supplier development is a right thing to do. Yet, existing studies have remained silent on how to do the things (i.e., supplier development) right, and factors that could potentially enhance a buyer's efficiency of utilizing supplier development practices are unexplored-a gap this study aims to fill. More specifically, the findings of this study shed lights on "how well the resources expended are utilized" (Fugate et al. 2010, 45) such that buying firms not only do the right thing (by investing in supplier development programs) but also do things right.

Consistent with the literature, supplier development represents a specific asset a buyer invested in their suppliers (Krause 1997) that the ending of a given relationship will render little value of such an asset. Supplier development, as such, exposes a buyer to transaction costs (i.e., transaction risk and coordination costs) from a transaction cost economics (TCE) perspective. To enhance supplier development efficiency, buyers can reduce the transaction risk and coordination costs associated with their supplier development. This study investigates three such factors: relational norms, supplier information sharing, and buyer information sharing. There are two considerations that we focus on: relational norms, defined as a relationship between exchange partners based on mutual trust, concerns, and shared values (Heide and John 1992). First and theoretically, relational norms is built with the intent of reducing transaction costs stemming from asset specificity, that is, supplier development (buyer's relationship-specific investment) in this study. Second and extending from the first consideration, whether the reduced transaction costs associated with relational norms offsets the increased transaction costs associated with asset specificity is, nevertheless, an empirical question (Artz and Brush 2000). To the best of our knowledge, the dialectical opposition between relational norms and asset specificity (i.e., supplier development in this study) has not been explored. Thus, by examining the effect of relational 
norms in a supplier development context, findings of this study can provide managers with guidance about prioritizing resources and make theoretical contributions to better understand transaction costs empirically, one of TCE's key concepts.

With respect to information sharing, TCE has been documented as one of the most prevalent theoretical lenses (Kembro and Näslund 2014). Whereas buyer information sharing can reduce transaction costs by reducing coordination costs associated with conflict resolution ( $\mathrm{Li}$ et al. 2012) and/or misunderstanding resulting from divergent viewpoints (Forker et al. 1999), supplier information sharing can reduce transaction costs by reducing supply uncertainty (Li and Lin 2006) and by reducing a buyer's coordination costs (Dyer 1997). In short, TCE informs our choice of factors. In addition, our focus of these three factors, particularly relational norms, furthers our understanding of TCE and its applicability in a supplier development context.

Further, existing supplier development literature often examines information sharing as a single factor, specifically, information shared by the buying firm (Humphreys et al. 2004; Krause et al. 2007). This study extends the existing literature by considering information sharing from both the buyer's and supplier's perspectives. In the existing literature, the role of a buyer is to initiate supplier development and a supplier responds to such an initiative (Krause et al. 2007). Specifying information sharing into buyer versus supplier better captures the subtle yet crucial differences between a strategic (proactive) act and a collaborative (reactive) response. Second, differentiating between buyer and supplier improves the understanding of information sharing both conceptually and empirically. Conceptually, a closer look at the existing supplier development literature indicates the concept of information sharing is, in fact, buyer information sharing. For example, "effective communication" is described as "open and frequent communication between buying firm personnel and their suppliers" (Humphreys et al. 2004, 134), or "buying firm respondents were asked to specify the extent of their willingness to share information with the supplier" (Krause et al. 2007, 536). Empirically, differentiating information sharing into two separate concepts can provide both the buyer and the supplier with more specific guidance in a situation where the same act from two sides may have different effects. In sum, differentiating information sharing between buyer and supplier highlights another major difference between this study and the existing supplier development literature.

This study utilizes the stochastic frontier analysis (SFA) (Battese and Coelli 1995). SFA allows researchers to relax the assumption that firms are technically efficient (always produce the maximum amount of output with a given set of inputs) in estimating a production function, an assumption that is necessary using ordinary least squares regression (Greene 2008). In other words, SFA allows us to model the actual (in)efficiency, as opposed to assuming firms are fully efficient in their use of inputs - an assumption that is rarely warranted in reality. Since we assume that a firm's efficiency regarding producing output (e.g., supplier performance) using supplier development practices as inputs vary and influenced by other factors, SFA is more appropriate than traditional regression approach. Further, SFA allows us to infer an objective measure of supplier development efficiency (deviation from the efficiency frontier) rather than directly assessing efficiency in a subjective manner (Chen et al. 2015).

Figure 1 shows the theoretical model examined in this study. Using a sample of 261 manufacturing plants from 11 countries, this study finds that relational norms and supplier information sharing each improves supplier development efficiency. Contrasting to expectation, we find that buyer information sharing could degrade supplier development efficiency. Robustness analyses using an alternative two-stage approach and data envelopment analysis (DEA), an alternative frontier methodology, are consistent with the main results. Discussions and future directions conclude this study.

\section{LITERATURE REVIEW}

\section{Practices related to supplier development}

The term supplier development was first used as early as 1966 (i.e., Leenders 1966) to refer to manufacturers' efforts to increase viable suppliers and improve the subsequent supplier performance. Such an effort was triggered by the "Buy Canadian" policy in the early 1960s, during a time when many Canadian suppliers had poor quality. Poor supplier quality compounded with the weak Canadian dollar (against the U.S. dollar) at that time render “. . .the buyer's responsibility... not to select, but to create a satisfactory source" and as such, a "purchaser does not select supplier development as an appropriate technique or tool; it is the only course left, apart from in-plant manufacture" (Leenders 1966, 54). Since then, supply chain management researchers have discussed supplier development process (Hahn et al. 1990; Hartley and Choi 1996; Krause et al. 1998), practices (Krause et al. 1998; Reed and Walsh 2002; Wagner 2006), factors preceding buyer's investment in supplier development programs (Krause 1999), and results of supplier development programs and from which identifying successful factors (Krause and Ellram 1997a,b) and barriers (Lascelles and Dale 1989). Strategicoriented supplier development involves those practices in which a buying firm takes an active role and dedicates physical and human resources directly to a specific supplier with the goal of increasing supplier performance to better meet the buying firm's needs. Exemplary practices include, but not limited to, providing

Figure 1: Theoretical model.

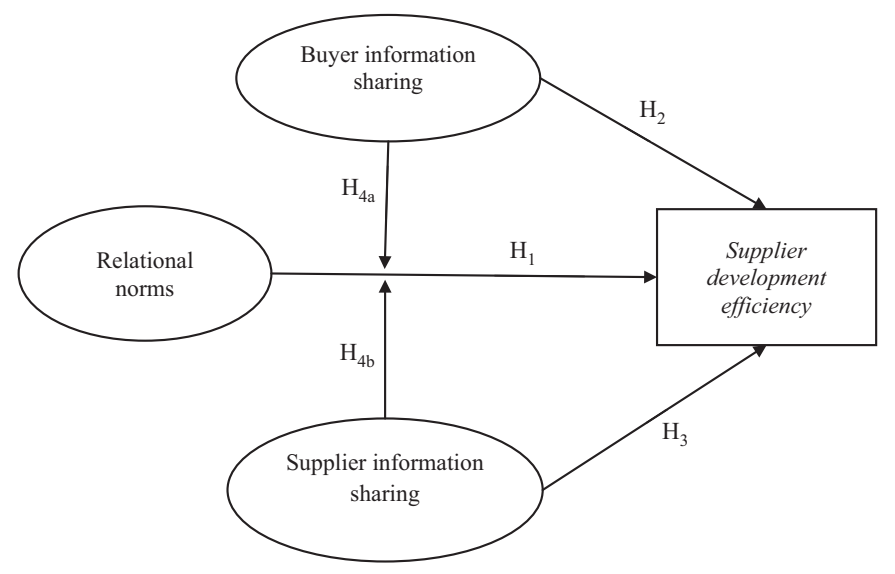


formal evaluation, supplier site visits, feedback, and supplier training (Krause 1997; Krause et al. 2000).

Table 1 summarizes exemplary work on supplier development. We highlight some observations from Table 1. First, previous studies largely focus on the effectiveness of supplier development by examining relationships between supplier development practices and business performance (Wagner 2011), supplier performance (Modi and Mabert 2007), and buyer performance (Krause et al. 2000). Very few studies discuss how to enhance the extent of efficiency with which a firm utilizes those practices to achieve ideal supplier performance. Second, in terms of methodology evolutions, early works are conceptual in nature and much of them built on case studies; empirical studies became more dominant as time progresses, and survey appears to be the most commonly adopted approach for data collection. Besides the content novelty (efficiency in this study vs. effectiveness in the extant literature), our stochastic frontier approach adds another novelty to the stream of supplier development literature. The third observation pertains to the studied contexts and subsequent generalizability. As aforementioned, the term supplier development was first coined by Leenders (1966) for studying Canadian manufacturers. With this genesis, the first wave of studies are North American dominant (particularly auto industry related) with sporadic attention from Asia (e.g., Humphreys et al. 2004), and finally, there was a systematic interest from Europe, notably by Wagner $(2006,2010,2011)$ who collected data from Germany, Switzerland, and Australia and published a series of studies on this subject of matters. The data used in this study encompass responses from 11 countries across three continents, so the findings of this study can improve generalizability.

\section{A transaction cost economics view of supplier development}

This study uses TCE, one of the most commonly evoked theories in the existing literature (e.g., Krause 1999; De Toni and Nassimbeni 2000; Krause et al. 2000; Humphreys et al. 2004), as the theoretical lens. TCE is appropriate for this study concerns a strategic-oriented supplier development program (Krause et al. 1998). Two key assumptions characterize TCE: bounded rationality and opportunism. Both are relevant to the context of supplier development (Rindfleisch and Heide 1997). Bounded rationality refers to both the neurophysiological and language limits of individuals (Simon 1955). Decision makers, while attempting to act rationally under conditions of uncertainty, are constrained by bounded rationality. As such, bounded rationality gives rise to transaction costs, defined as the sum of coordination costs and transaction risk, that need to be minimized (Williamson 1991). Opportunism refers to behaviors in which individuals act in their own self-interest (Williamson 1985). Similar to bounded rationality, the existence of opportunism gives rise to transaction costs (Williamson 1981, 1985). Since a supplier development program is often tailored for a given supplier, from a buyer's perspective, supplier development practices are often relationship specific (i.e., high asset specificity that has low transferability to other relationships). Therefore, supplier development practices can be seen as relationship-specific assets with high asset specificity (Krause 1997; Modi and Mabert 2007). These relationship-specific assets inevitably expose buyers to transaction risk and coordination costs. For instance, the supplier might take advantage of the buyer's sunken investment that increases transaction risk (e.g., supplier opportunism, supply uncertainty) (Grover and Malhotra 2003). Developing a supplier also necessitates high coordination costs to the buyer, ranging from the ex ante supplier selection (search cost) and contracting efforts (contracting cost) to the ex post efforts in verifying supplier compliance and evaluating performance (monitoring cost and enforcement cost if sanctions are levied) (Grover and Malhotra 2003). In summary, the TCE perspective prescribes that the buyers would incur coordination costs and transaction risk with the implementation of supplier development practices due to opportunism and bounded rationality. Therefore, a buyer can increase its supplier development efficiency by reducing the transaction costs accompanying by supplier development practices.

\section{HYPOTHESIS DEVELOPMENT}

Per TCE, the high asset specificity nature of supplier development practices entails coordination costs and transaction risk to a buyer, which affect the utilization of resources. Building relational norms could help curb supplier opportunism and lower transaction costs (Frazier et al. 1988; Heide and John 1988), and hence increase supplier development efficiency. When high relational norms exists, a buyer could spend less time and resources on monitoring efforts, thus reducing buyer's coordination costs (Dyer and Chu 2003; Nyaga et al. 2010). In addition, high relational norms serves as a better safeguard if a given relationship continues, reducing the transaction risk. In a sense, a high degree of relational norms allows buyers to focus more on realizing the full benefits of the supplier development practices without worrying about suppliers taking advantage of the buyer's investment. This is in line with the extant supplier development literature that the buying firms' perspective toward suppliers has been identified as one of the antecedents to supplier development programs (Krause 1999) and that transaction-specific supplier development is influenced by trust and long-term commitment (Li et al. 2012). In contrast, buyers in a relationship characterized by a low degree of relational norms may not realize the full potential of supplier development practices because their concern of supplier opportunism would entail more ex post efforts and incur higher monitoring and enforcement costs, negatively impacting supplier development efficiency. Further, suppliers in a relationship characterized by a high degree of relational norms may be more willing to provide their expertise and work with buyers on realizing the benefits of supplier development practices. Conversely, with a low level of relational norms, suppliers may refrain themselves from participating in buyers-initiated supplier development activities, suspecting buyers may consistently act in their own interest (Nagati and Rebolledo 2013). Therefore, a relationship with high relational norms helps buyers better realize benefits from supplier development practices and helps suppliers to fully participate in those practices and ultimately improve their supplier performance. In sum, we posit that high relational norms reduces transaction costs associated with supplier development practices and improves a buyer's supplier development efficiency. 
Table 1: Supplier development: an exemplary review of literature

\begin{tabular}{ll} 
Reference & Nature of the study \\
\hline Leenders (1966) &
\end{tabular}

Hahn et al. (1990) Conceptual

Watts and Hahn (1993) Empirical (survey)

Hartley and Choi (1996)

Krause and Ellram (1997b)

Krause and Ellram (1997a)

Krause et al. (1998)

Empirical (survey)

\section{Main content}

-first use of the term "supplier development" (SD) as part of the supplier selection process, particularly (but not limited to) selecting new source -use SD to refer to (Canadian) manufacturers' efforts to increase viable supply source and improve subsequent supplier performance -defines a broader view of SD as "situation in which the purchaser can see unusual benefits for the potential supplier (of which the supplier is unaware) if he can be persuaded to undertake the contract" (p. 54) -discuss both a "narrow" perspective of SD that aims to develop a supplier that has not delivered products to a focal firm before, and a "broad" perspective that pertains to developing an extant supplier -present a two-dimensional matrix and categorize SD activities. One dimension is related areas (product, process, and operating systems related), and the other dimension is capabilities (technical, quality, delivery, and cost)

-present a conceptual model that outlines the organizational decision process of a supplier development program

-survey to determine the level of involvement in SD and the results indicated that large firms are more likely to be involved

-assess the success of the SD programs and the results confirmed the importance of formal supplier evaluation in the SD process

-assess the effectiveness of SD by rating a series of questions using 7-point Likert scales, with quality and delivery related activities receiving highest ratings

-describe supplier development process

-identify four factors that instrumental to sustain and spread improvement activities throughout a supplier organization: (1) hands-on training of supplier team members, (2) regular follow-up and measurement by the customer, (3) fit between the improvement approach and supplier firm's culture, (4) support in the supplier's organization

-survey firms' experience about their supplier development programs and different firms into "fallen short" and "exceeded" groups

-show that the two groups are significantly different in formal evaluation, providing feedback of evaluation results, use of a supplier certification program, site visits to the suppliers, visits to the buying firm by supplier's representatives, supplier recognition, training and education of the supplier's personnel, and investment in the supplier's operation by the buying firm -majority of buyers involved in SD will perceive their suppliers as partners -buyers involved in SD emphasize on sharing information with suppliers, top management involving in buyer-supplier relationship, cross-functional teams, and purchase a larger percentage of the supplier's annual sales -differentiate between reactive versus strategic SD: The former aims to improve poor supplier performance and eliminate deficiencies, whereas the latter aims for continuous improvement of supply base with a focus on long-term competitive advantages

-describe a generic 10-step process model of SD

-differentiate between supplier assessment on performance and assessment system of capabilities

-present three propositions regarding circumstances/conditions that under which firms are more likely to participate in strategic SD programs 
Table 1: (Continued)

\section{Reference}

Krause (1999)

Krause et al. (2000)

De Toni and

Nassimbeni (2000)

Reed and Walsh

(2002)

Humphreys et al. (2004)

Wagner (2006)

\section{Nature of the study}

1. Empirical: survey

2. Structural equation modeling (SEM)

1. Empirical (survey from 279 manufacturing firms)

2. SEM

1. Empirical (survey)

2. Multivariate analysis (canonical correlation, discriminant analysis)

Case study (12 interviews)

1. Empirical (survey)

2. Regression analysis

1. Empirical (case studies and survey)

2. Exploratory factor analysis

\section{Main content}

-apply transaction cost theory and classify antecedents into three groups: the environmental and influence factors (market competition, rate of tech change, top management support, importance of inputs to the buying firm); the attitudinal factor (buyer's attitude toward suppliers); and the barrier factors (supplier commitment, interfirm communication, buyer's expectation of relationship continuity)

-the proposed model is mostly supported except that rate of tech change does not influence buyer's perspective toward suppliers and that buyer's expected relationship continuity does not influence SD activities

-apply transaction cost theory, resource-based theory, and internalization theory to categorize SD strategies as internalized (conceptualized using the transaction cost theory) versus externalized (conceptualized using the resource-based theory) activities

-examine the impact of SD activities on supplier performance and show that while direct involvement activities (i.e., internalized SD strategy) play a critical role in performance improvement, external activities (supplier incentives and supplier assessment) exert their impact via direct involvement

-document and show which dimension of SD is important for successful just-in-time implementation; among the three, the "design link" is most closely connected to SD

-specifically, all three links ("quality link," "logistics link," and "design link") are connected to the "supplier assistance and training" SD practice, and both "logistics and design links" are connected to the "organizational integration" SD practice, and only the "design link" is connected to the "contractual incentives" SD practice

-describe and differentiate SD as a practice that is either reactive (to deal with poor supplier performance) or strategic (to enhance the supply base's long-term capability). This differentiation is in line with Krause et al. (1998)

-propose that buyers prioritize supplier capabilities on quality, cost, and delivery over technological capability in their SD programs -transaction-specific SD predicts buyer-supplier performance improvement -infrastructure factors such as trust, supplier strategic objectives, and effective communication play an important role of buyer-supplier performance

-direct SD is correlated to infrastructure factors of SD, indicating SD is not an isolated behavior of the buying firms

-combine qualitative (case studies) with quantitative (survey across firms in three German-speaking countries: Germany, Switzerland, and Austria) approach

-differentiate SD into direct (internalized) and indirect (externalized): The buying firm plays an active role and dedicates human and/or capital resources to a specific supplier in the former, whereas the buying firm commits little or no resources to a specific supplier in the latter -direct SD activities involve human and capital investment, whereas indirect SD activities involve both ad hoc (occasional) and regular supplier evaluations, evaluation system and process, communication 
Table 1: (Continued)

\begin{tabular}{|c|c|}
\hline Reference & Nature of the study \\
\hline Wagner (2010) & $\begin{array}{l}\text { 1. Empirical paper (survey } \\
\text { sent to industrial and service } \\
\text { firms in three European } \\
\text { countries) }\end{array}$ \\
\hline & 2. Regression analysis \\
\hline
\end{tabular}

Wagner (2011)

1. Empirical (survey across three German-speaking countries)

2. Regression analysis

Nagati and Rebolledo (2013)
1. Empirical (survey)

2. Partial least square

(variance-based SEM)

\begin{abstract}
Main content
-differentiate SD activities into direct versus indirect and investigate their respective relationships to supplier performance

-discuss various theoretical lens applied in the existing studies, including theories relevant to the links between indirect SD activities and performance (goal-setting theory, the concept of "influence strategy") and those relevant to the links between direct SD activities and performance (TCE and knowledge-based view of the firm)

-found that (1) indirect SD improves suppliers' performance and capabilities, (2) direct SD improves suppliers' capabilities only, and (3) firms should engage in either indirect or direct SD but not in both simultaneously -draw on social capital theory to show that the length of the buyer-supplier relationship can better explain the links between direct SD activities and performance: Relationship length is used as a proxy for the life cycle of a given relationship

-the effectiveness of a given SD activity is moderated by relationship life cycle

-survey manufacturing sectors in Canada

-adopt a supplier viewpoint and show that supplier's trust, preferred customer status, and environmental dynamism all impact SD activities and the subsequent supplier performance
\end{abstract}

\section{$\mathbf{H}_{\mathbf{1}}$ : Relational norms is positively associated with supplier development efficiency.}

Information sharing between a buyer and a supplier is another key approach to encouraging conflict resolution (Spekman 1988; $\mathrm{Li}$ et al. 2012) and has been identified as a critical element in successful supplier development (Krause and Ellram 1997b). Buyer information sharing is the extent to which a buyer openly shares information with a supplier (Paulraj et al. 2008). Buyers who share information with suppliers could help their suppliers better realize the benefits of supplier development practices, improving the supplier development efficiency. To start with, open communication pertaining to the scope and goal of supplier development helps reduce contracting efforts, thereby reducing coordination costs. For example, buyers who share product quality information may help their suppliers better utilize the quality control training offered by the buyer. Similarly, buyers who share demand information may help the supplier better utilize the forecasting training provided by the buyers. Also, divergent viewpoints may lead to different understandings about supplier development (Forker et al. 1999), which increases transaction risk. Buyers who share information with suppliers could reduce the likelihood of misunderstanding, assuring the suppliers that buyers are interested in the success of the supplier development. Thus, we propose the following:

\section{$\mathbf{H}_{2}$ : Buyer information sharing with suppliers is positively associated with supplier development efficiency.}

Interfirm communication is a two-way street. Supplier information sharing, a mirrored concept of buyer information sharing, is the extent to which a supplier openly shares information with a buying firm from which the supplier receives assistance. From the TCE perspective, supplier information sharing could increase supplier development efficiency by reducing transaction risk and the associated coordination costs. A supplier sharing information with its buyers could reduce supply uncertainty ( $\mathrm{Li}$ and $\mathrm{Lin}$ 2006; Yu et al. 2013). Supply uncertainty can preclude a buyer's ability to verify and ensure supplier compliance and gives rise to transaction risk and increases coordination costs. Suppliers sharing information such as updates on delivery schedules, production cost, and product quality reduce supply uncertainties for buyers (Lin et al. 2002; Grover and Malhotra 2003). Supplier sharing those pieces of information may also indicate supplier commitment, which has been found as one of the critical antecedents to the success of supplier development programs (Krause 1999). Supplier information sharing could also reduce a buyer's coordination costs (Dyer 1997). For example, suppliers sharing production and delivery schedule information could reduce a buyer's costs in coordinating internal activities. Past study also shows that sharing product quality information could reduce a buyer's costs related to ensuring supplier compliance (Dyer 1997). Thus, we propose the following:

\section{$\mathbf{H}_{3}$ : Supplier information sharing with buyers is positively associated with supplier development efficiency.}

Last, we theorize that relational norms and information sharing by buyer and by supplier could jointly influence supplier development efficiency by reducing transaction costs. For buyers, supplier development practices subject a buyer to supplier opportunism, increasing transaction costs for buyers. A high 
level of relational norms reduces transaction costs and encourages frequent and open information sharing with their suppliers (Heide and John 1992), which further reduces transaction risk and coordination costs.

Similarly, from a supplier's viewpoint, on the one hand, suppliers sharing confidential information expose them to buyers' opportunism; on the other hand, suppliers' willingness to share information signals their trust in buyers and characterizes a high level of relational norms, which further curbs opportunism and reduces transaction costs (Nagati and Rebolledo 2013).

Specific to the context, we posit that information sharing and relational norms together promote a better environment for joint problem solving (Watts and Hahn 1993; McEvily and Marcus 2005; Modi and Mabert 2007), which increases supplier development efficiency. Relational norms promotes involving not just purchasing personnel but also engineers in the supplier development process (Reed and Walsh 2002). Further, relational norms encourages behaviors toward collective goals and mutual benefits. Information sharing increases both buyer and supplier's awareness of potential supplier development problems and opportunities. Joint problem solving becomes more efficient with the exchange of sensitive and/or proprietary information and with the exchanged partners both willing to listen and accept suggestions. Taken together, relational norms and information sharing jointly create an environment that facilitates joint problem solving, which helps increase supplier development efficiency.

\section{$\mathbf{H}_{\mathbf{4 a}}$ : There exists a synergistic effect between relational norms and buyer information sharing on supplier develop- ment efficiency. \\ $\mathbf{H}_{\mathbf{4} \mathbf{b}}$ : There exists a synergistic effect between relational norms and supplier information sharing on supplier devel- opment efficiency.}

\section{DATA AND SAMPLE}

This study uses part of the data collected by the fourth round of the High-Performance Manufacturing (HPM) research project (Schroeder and Flynn 2001). HPM is a large-scale global research project that involves a team of international researchers. HPM examines manufacturing practices at the plant level in three specific industries: electronics, machinery, and transportation. Many studies have been published based on previous rounds of HPM project. The fourth-round HPM data involve manufacturing plants in 11 countries (China, South Korea, Japan, Taiwan, Brazil, Germany, Sweden, Finland, Israel, Italy, and Spain). Participation in HPM requires extensive efforts on the part of the plant. To increase a firm's willingness to participate, research team members spent a significant amount of time with prospective firms to explain the benefits of participation in the study. Researchers rely on their own personal or on university networks to contact prospective firms. Once a firm agrees to participate, the firm manager identifies a highperforming plant with at least 100 employees for the survey. To reduce the potential impact of unobserved firm-level variations, each participating firm is limited to one plant. The plant coordinator receives a package that consists of 12 survey questionnaires, which cover different manufacturing and environmental aspects (e.g., supply chain, operations, human resources, competitive environment) for distribution to the appropriate respondents. To increase the accuracy of information, the survey requires the respondents' expertise or job titles to be directly related to the survey questions. In this study, two upstream supply chain managers (e.g., purchasing manager) respond to the survey questions. Measurement items are mixed in the questionnaires to reduce the context effects (Tourangeau et al. 2003). Using multiple respondents and mixed survey items help reduce the common method bias (Podsakoff et al. 2003). The final data set consists of 261 plants. Consistent with the previous round of HPM project (e.g., Zhang et al. 2012), the response rate varies across countries and is approximately 60 percent as indicated in a recent study (Turkulainen et al. 2017). Table 2 provides the sample distribution across countries and industries.

\section{METHODOLOGY}

SFA estimates an individual unit's inefficiency as the distance to the efficient frontier (Battese and Coelli 1995; Lieberman and Dhawan 2005; Chen et al. 2015). Specifically, SFA constructs an efficient frontier, which is the ideal output level achieved given a specific set of inputs among a group of units (see Figure 2). The inefficiency term infers a unit's efficiency of transforming "the inputs available to it ... and converts them into whatever output it desires. .." (Dutta et al. 2005, 278). Therefore, the closer a unit to the frontier, the better the unit's relative efficient use of resources. In this study, we operationalize supplier development (in)efficiency using the inefficiency term described in the following paragraph (Table 3).

\section{Stochastic frontier analysis}

SFA decomposes the observed output into three elements: the ideal output (i.e., the desired outcome) determined by a set of inputs (i.e., resources), the random error term, and the

Table 2: Sample distribution across industry and country

\begin{tabular}{|c|c|c|c|c|}
\hline Country & Electronics & Machinery & Transportation & Total \\
\hline Brazil & 5 & 6 & 9 & 20 \\
\hline China & 10 & 10 & 10 & 30 \\
\hline Finland & 6 & 6 & 5 & 17 \\
\hline Germany & 6 & 13 & 9 & 28 \\
\hline Israel & 21 & 5 & 0 & 26 \\
\hline Italy & 7 & 17 & 5 & 29 \\
\hline Japan & 6 & 7 & 8 & 21 \\
\hline Spain & 6 & 8 & 11 & 25 \\
\hline Sweden & 4 & 4 & 1 & 9 \\
\hline $\begin{array}{l}\text { South } \\
\text { Korea }\end{array}$ & 8 & 5 & 13 & 26 \\
\hline Taiwan & 19 & 9 & 2 & 30 \\
\hline Total & 98 & 90 & 73 & 261 \\
\hline
\end{tabular}


Figure 2: Illustration of the efficient frontier.

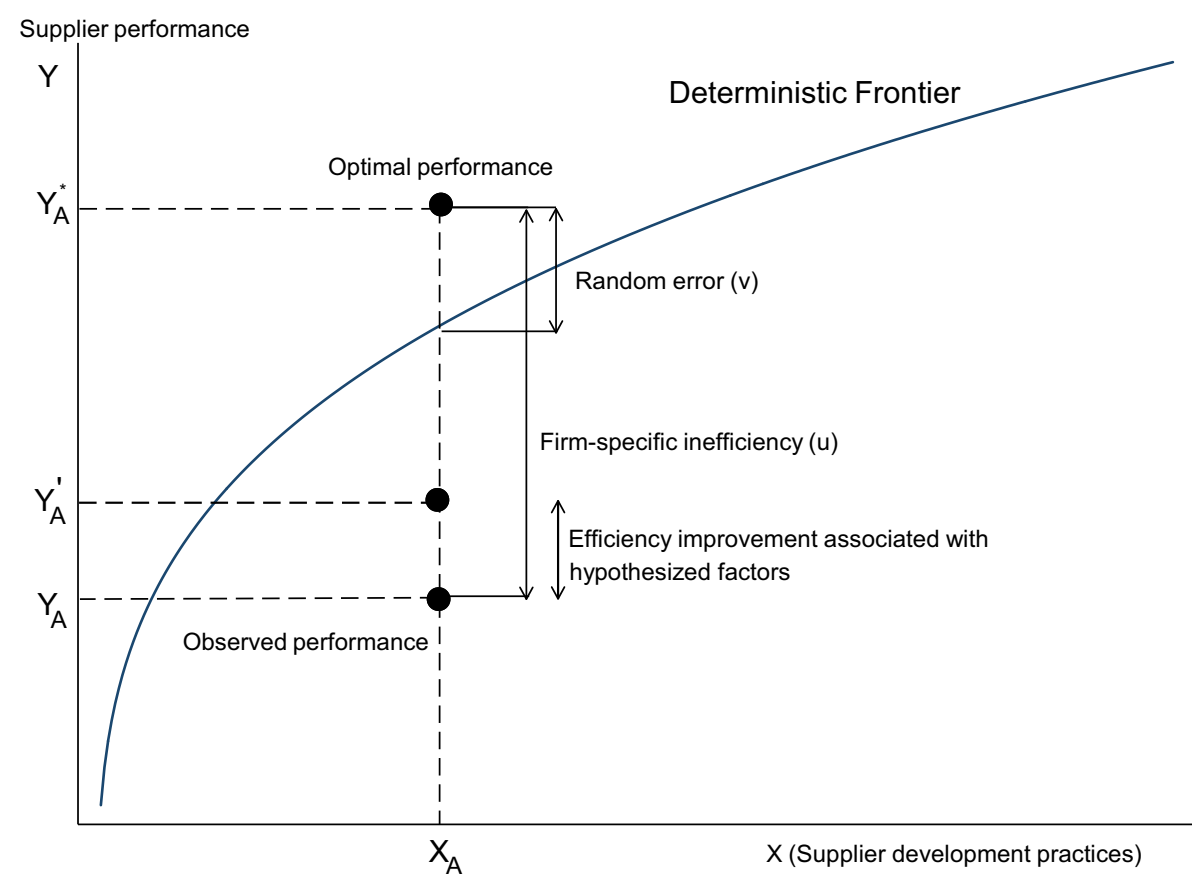

Table 3: Summary statistics and correlations

\begin{tabular}{|c|c|c|c|c|c|c|c|c|}
\hline & Mean & SD & 1 & 2 & 3 & 4 & 5 & 6 \\
\hline 1. Supplier performance & 3.663 & 0.513 & 1 & & & & & \\
\hline 2. Plant size & 844.117 & 1994.74 & 0.084 & 1 & & & & \\
\hline 3. Supplier development initiative & 3.786 & 0.595 & $0.575 * *$ & $0.156^{*}$ & 1 & & & \\
\hline 4. Supplier evaluation & 3.859 & 0.905 & $0.438 * *$ & $0.161 *$ & $0.591 *$ & 1 & & \\
\hline 5. Relational norms & 3.867 & 0.540 & $0.563 * *$ & 0.037 & $0.645 * *$ & $0.453 * *$ & 1 & \\
\hline 6. Buyer information sharing & 3.194 & 0.953 & $0.330 * *$ & 0.038 & $0.284 * *$ & $0.264 * *$ & $0.143^{*}$ & 1 \\
\hline 7. Supplier information sharing & 3.143 & 0.899 & $0.483 * *$ & 0.009 & $0.355^{* *}$ & $0.382 * *$ & $0.241 * *$ & $0.663 * *$ \\
\hline
\end{tabular}

$\dagger p<0.1,{ }^{*} p<0.05,{ }^{* *} p<0.01,{ }^{* * *} p<.001$.

inefficiency term (Aigner et al. 1977; Meeusen and van Den Broeck 1977). The stochastic frontier model has the following formation:

$Y_{i}=f\left(\mathbf{X}_{i} ; \boldsymbol{\beta}\right)+v_{i}-u_{i}$

where $Y_{i}$ is the actual output; $f\left(\mathbf{X}_{i} ; \boldsymbol{\beta}\right)$ is the production function, which denotes ideal output as a function of a set of inputs $\mathbf{X}_{i}$ with unknown coefficients $\boldsymbol{\beta}$. The production function in Equation (1) represents the idealized efficient frontier - the maximum expected output given inputs $\boldsymbol{X}$, common to all sample organizations. Variable $v_{i}$ captures the random errors affecting outputs due to unobserved inputs or measurement errors in data. Finally, $u_{i}$ depicts the relative distance to the efficient frontier, that is, the inefficiency of an individual unit $i$ regarding transforming inputs to an output.

Figure 2 illustrates the notion of the efficient frontier with one input and one output, where the value of the input $X$ is shown on the horizontal axis and output $Y$ is shown on the vertical axis. The deterministic efficient frontier reflects the existence of diminishing returns to scale. As illustrated, firm A uses input $X_{A}$ to produce the observed output $Y_{A}$. If firm A is fully efficient in utilizing resources (i.e., there is zero inefficiency: $u=0$ ), then firm A should achieve the ideal output $Y_{A}^{*}=f(x)+v$. When the random noise $(v)$ is positive, the ideal output lies above the deterministic efficient frontier.

The main contrast of SFA and traditional least square regression approach is that the traditional approach attributes the deviation from the efficient frontier to random error $v_{i}$ only, while SFA recognizes firm-specific inefficiency $u_{i}$ as a potential cause of the deviation. SFA also allows exogenous variables to affect the extent of inefficiency $u_{i}$. The three most common assumptions of the inefficiency term in SFA are exponential, half-normal, and truncated normal (Aigner et al. 1977; Stevenson 1980). The choice of distribution assumption is typically computational rather than theoretical (Coelli et al. 2005) for SFA. Since the 
truncated normal assumption is not able to converge on our data, we opt for a more parsimonious half-normal model. We consider the half-normal assumption by Caudill and Ford (1993), Caudill et al. (1995), and Hadri (1999), which allows heteroskedasticity in the distribution of $u_{i}$ to analyze the effects of exogenous factors on inefficiency $u_{i}$. Equations (2) and (3) specify the halfnormal inefficiency model.

$u \sim\left|N\left(0, \sigma_{u}^{2}\right)\right|$

$\sigma_{u i}^{2}=\exp \left(\delta^{\prime} Z_{i}\right)$

In Equation (3), a positive value of the $\delta$ coefficient indicates that as the level of exogenous variable $Z$ increases, so does the variance of technical inefficiency $\left(\sigma_{u}\right)$. A negative $\delta$ indicates that the exogenous variable reduces the variance of technical inefficiency. Last, we adopt a one-step approach and estimate the production function and the inefficiency model simultaneously following recommendations by Chen et al. (2015).

\section{Measurements}

Inputs and output of the production function

Prior studies have used managerial practices as inputs because they represent resources utilized in generating outcomes (e.g., Narasimhan et al. 2001). This study views supplier development practices as the inputs $\boldsymbol{X}$ and supplier performance as the output $Y$ of the production function in Equation (1) because the focus is on the buyer's supplier development efficiency. Several supplier development-related practices have been discussed in the literature. The construct of supplier development initiative captures the practices that require a buying firm's active involvement, such as providing technical assistance, training, and joint meetings (Krause 1997; Swink et al. 2005; Narasimhan et al. 2009). The construct of supplier evaluation measures the extent of a buying firm having a formal supplier evaluation system, which is an important practice in supplier development (Krause et al. 1998). The construct of supplier performance captures multiple supplier performance dimensions such as conformance, cost, ontime delivery, and willingness to meet a buyer's requirements (Johnston et al. 2004). Last, we include both country and industry dummies in the production function to control for the potential effects on supplier performance. Please see the Appendix for detailed survey items.

\section{Hypothesized factors in the inefficiency model}

The measurements of hypothesized factors $\boldsymbol{Z}$ in the inefficiency model in Equation (3) are also adapted from the existing supply chain literature. The relational norms construct, adapted from Min et al. (2007), assesses the extent of supplier relationship in terms of supplier benevolence (Kumar et al. 1995; Min et al. 2007) and shared understanding between buyer and supplier. We conceptualize the extent of information sharing as a firm's willingness to share all kinds of information. To reflect this conceptualization, we model both buyer's and supplier's information sharing as reflective scales - high information sharing indicates high extent of willingness to share all relevant information, as opposed to formative scales-high information sharing can be achieved by high extent of willingness to share selective information. Specifically, the buyer information sharing construct measures several types of information (e.g., production, delivery, and scheduling) shared by buyers with their suppliers (Zhou and Benton 2007). We asked the purchasing managers the information they shared with their major suppliers. Similarly, the supplier information sharing construct measures the information shared by suppliers with their buyers. We asked the purchasing managers whether they have access to the information from their major suppliers. Rather than focusing on a firm's willingness to share information (Monczka et al. 1998), these two constructs focus on the content of the information shared by suppliers and buyers (Zhou and Benton 2007).

Finally, plant size may influence the efficiency of utilizing supplier development practices. For example, a large plant may have more personnel and capital to invest in supplier development activities (Blonska et al. 2013). Therefore, plant size is included as a control variable in the inefficiency function and measured as the natural logarithm of the number of employees in a plant (Dean and Snell 1991).

\section{Country differences across measurement items}

Since the survey data come from multiple countries, the respondents across countries could interpret the measurement items differently due to culture or language differences. To ensure measurement invariance, we use the recently developed alignment method for multiple-group factor analysis (Asparouhov and Muthén 2014), which is a procedure implemented in Mplus 7.1. The alignment method is an optimization approach that identifies an optimal pattern of measurement invariance solution and detects groups that deviate from the optimal pattern. The alignment method is a two-step approach. In the first step, the alignment method fits a configural invariance model across groups using maximum likelihood method with loadings and intercepts freed, factor means fixed at zero, and factor variances fixed at one. In the second step, the method estimates the factor means and variances to minimize the total amount of measurement variances across all parameters by applying a simplicity function that works as the rotation criteria for the exploratory factor analysis (Asparouhov and Muthén 2014, 496-498). The estimation procedure is an iterative approach with different starting values until the procedure reaches an optimal and stable solution. Finally, the alignment method reports the optimal solution (the best measurement invariance pattern) and provides information to assess the degree of noninvariance across groups. The results of the alignment method indicate that the number of groups with approximate measurement invariance in factor loading is high. Asparouhov and Muthén (2014) suggest the number of measurement noninvariance items should be lower than $20 \%$ of the total items for the factor means to be comparable across groups. Our result is well below the $20 \%$ cutoff (only one item shows sign of measurement noninvariance; please see the Appendix for details). As a result, we proceed with confirmatory factor analysis (CFA).

\section{Psychometric properties of constructs}

This research uses CFA to assess the psychometric properties of the survey constructs. We drop the items with standardized factor 
loadings below the normally accepted level of 0.6 (Fornell and Larcker 1981; Shah and Goldstein 2006). Most of the average variance extracted (AVE) values are greater than 0.5 , which indicates convergent validity (Hair et al. 2006), except supplier development initiative (0.475). The AVE is slightly below 0.5 due to the lower factor loading of one survey item (we offer the necessary training to our suppliers). We decided to keep this item for a theoretical reason since this item represents an activity of supplier development that requires buyers' active participation. Composite reliability (CR) coefficients ranged from 0.7 to 0.9 , which exceed the recommended 0.7 benchmark for construct reliability (Henseler et al. 2009). The square root of the AVE for each hypothesized factor is also greater than the correlations between the hypothesized factors (Gefen and Straub 2005; Hair et al. 2006). The overall model fit statistics are all above the recommended standards (root mean square error of approximation $=0.055$ with PCLOSE value $=0.167$, comparative fit index $=0.946$, Tucker Lewis index $=0.938$, standardized root mean square residual $=0.052$ ) (Hu and Bentler 1995, 1999). We also perform a bootstrapping procedure with 1,000 samples to address potential multivariate non normality. The model fit statistics are qualitatively similar. The Appendix documents the measurement item loadings, CR, and AVE of the constructs in this study.

We utilize the factor scores of each construct for subsequent analysis rather than the averages following suggestions from past research (Edwards and Wirth 2009). Factor scores are better than averaging indicators because averaging requires stronger assumptions regarding psychometric properties (averaging requires the indicators be parallel, whereas factor scores only require indicators be congeneric), and factor scores often have more symmetrical distributions (Edwards and Wirth 2009; Calantone et al. 2017). Factor scores are even more beneficial when researchers have data from multiple countries and concerns about measurement invariance (Flora et al. 2008).

\section{RESULTS}

We present the results with the half-normal distribution assumption for the inefficiency term. We also analyze the data with the exponential distribution assumption and the results are consistent. Table 4 reports the estimation results regarding the production function and inefficiency model using SFA. We use STATA 14 to perform the SFA (StataCorp 2015). The production function, which estimates the efficient frontier, includes the two supplier development practices (supplier development initiative and supplier evaluation) as inputs and supplier performance as output. We use the original factor scores for the production function without any transformation instead of the commonly used CobbDouglas production function since transforming the scores using natural logs changes the underlying equal spacing assumption of the Likert scales. Country and industry dummies are included in the production function as control variables. The estimated coefficients of the production function change only slightly across all four models (Table 4), with different specifications of the inefficiency model. This indicates a stable efficient frontier. The coefficients of supplier development initiative are significant across all models, suggesting a valuable resource for supplier performance. Conversely, supplier evaluation is not significant across all models.

Model 0 represents the baseline case. For the inefficiency model, Models 1-3 each includes one of the hypothesized factors; Model 4 includes all main effects, and Model 5 includes the interactions. The model diagnostics statistics (Akaike information criterion [AIC]/Bayesian information criterion [BIC]) show improvements when comparing Models 1-3 each to Model 4 but not Model 5. The primary focus of this study is the estimated coefficients in the inefficiency model. As discussed before, a negative estimated coefficient in the inefficiency model (Equation [3]) indicates a decrease in the variance of firm-specific inefficiency $u_{i}$, which denotes a positive effect on supplier development efficiency. Plant size, a control variable, is insignificant across all models. The estimated coefficient of relational norms is negative in Model 1 $(\delta=-2.284, p<.01)$, suggesting that relational norms has a positive effect on supplier development efficiency, but this effect is not robust to the inclusion of the information sharing predictor variables (Model 4, $\delta=0.022$, n.s.), which provides only partial support for $\mathbf{H}_{\mathbf{1}}$. The coefficient of buyer information sharing is not significant in Model $2(\delta=-0.169$, n.s.). Further, Model 4 shows the coefficient is positive, indicating a negative effect on supplier development efficiency $(\delta=2.767, p<.001)$. The results do not support $\mathbf{H}_{2}$. The estimated coefficients of supplier information sharing are negative and significant in both Model $3(\delta=-1.487$, $p<.01)$ and Model $4(\delta=-3.688, p<.05)$, suggesting that supplier information sharing has a positive effect on supplier development efficiency, which provides support for $\mathbf{H}_{3}$. Finally, Model 5 shows the interaction effects between relational norms, buyer information sharing, and supplier information sharing are not significant. The results do not support $\mathbf{H}_{\mathbf{4 a}}$ nor $\mathbf{H}_{\mathbf{4 b}}$. We discuss implications of the results further in Discussion and Conclusion section.

\section{Robustness analysis}

We present results using an alternative two-stage approach advocated by certain researchers (Banker and Natarajan 2008) as a robustness test. Researchers find that the coefficients remain statistically consistent even when the first-stage and second-stage variables are correlated (Johnson and Kuosmanen 2012). In the first stage, we estimate the efficiency score using SFA but excluding the hypothesized factors in the inefficiency function. In the second stage, we regress the logarithm of the efficiency score on the hypothesized factors (see the results in Table 5). The overall results are consistent with the main results using a one-step approach.

Additionally, we use DEA as an alternative frontier approach to examine the robustness of the study results (Banker et al. 1984). Prior studies often consider SFA and DEA as two common alternative frontier methodologies (Chen et al. 2015). We consider input-oriented DEA because the focus is on better resource utilization by changing the level or the mix of inputs. Further, this study assumes variable return-to-scale since increases in the extent of managerial practices do not necessarily result in a proportional change in perceived supplier performance. We apply a two-stage DEA estimation approach. In the first stage, we obtain each plant's supplier development efficiency score using DEA with supplier development initiative and 
Table 4: Estimates of the stochastic frontier analysis with half-normal distribution

\begin{tabular}{|c|c|c|c|c|c|c|}
\hline & Model 0 & Model 1 & Model 2 & Model 3 & Model 4 & Model 5 \\
\hline \multicolumn{7}{|l|}{ Production function } \\
\hline $\begin{array}{l}\text { Supplier } \\
\text { development } \\
\text { initiative }\end{array}$ & $1.162 * * *(0.100)$ & $0.912 * * *(0.112)$ & $1.151^{* * *}(0.109)$ & $1.144 * * *(0.092)$ & $1.159 * * *(0.111)$ & $1.151 * * *(0.119)$ \\
\hline $\begin{array}{l}\text { Supplier } \\
\text { evaluation }\end{array}$ & $-0.185(0.071)$ & $-0.111(0.056)$ & $-0.176^{*}(0.085)$ & $-0.223 * *(0.068)$ & $-0.235^{* * *}(0.063)$ & $-0.232(0.064)$ \\
\hline $\begin{array}{l}\text { Industry } \\
\text { dummies }\end{array}$ & Included & Included & Included & Included & Included & Included \\
\hline $\begin{array}{l}\text { Country } \\
\text { dummies }\end{array}$ & Included & Included & Included & Included & Included & Included \\
\hline \multicolumn{7}{|l|}{ Inefficiency model } \\
\hline Relational norms (RN) & & $-2.284 * *(0.757)$ & & & $0.022(0.787)$ & $-0.107(1.088)$ \\
\hline $\begin{array}{l}\text { Buyer } \\
\text { information } \\
\text { sharing }\end{array}$ & & & $-0.169(0.255)$ & & $2.767 * * *(0.699)$ & $2.760 * * *(0.733)$ \\
\hline $\begin{array}{l}\text { Supplier } \\
\text { information } \\
\text { sharing }\end{array}$ & & & & $-1.487 * * *(0.298)$ & $-3.688^{* * *}(0.617)$ & $-3.641^{* *}(0.664)$ \\
\hline $\begin{array}{l}\mathrm{RN} \times \text { Buyer } \\
\text { information } \\
\text { sharing }\end{array}$ & & & & & & $-0.293(1.265)$ \\
\hline $\begin{array}{l}\mathrm{RN} \times \text { Supplier } \\
\text { information } \\
\text { sharing }\end{array}$ & & & & & & $-0.076(1.063)$ \\
\hline Plant size & & $0.193(0.165)$ & $0.073(0.219)$ & $0.081(0.165)$ & $0.191(0.167)$ & $0.178(0.150)$ \\
\hline \multicolumn{7}{|l|}{ Variance parameters } \\
\hline$\sigma_{\mathrm{v}}$ & 0.256 & 0.268 & 0.259 & 0.251 & 0.238 & 0.238 \\
\hline$\chi^{2}$ & $550.44 * * *$ & $207.16^{* * *}$ & $486.41 * * *$ & $445.21 * * *$ & $260.82 * * *$ & $200.34 * * *$ \\
\hline $\begin{array}{c}\text { Log-pseudo } \\
\text { likelihood }\end{array}$ & -64.69 & -58.92 & -62.27 & -46.96 & -27.90 & -27.74 \\
\hline$N$ & 261 & 261 & 261 & 261 & 261 & 261 \\
\hline AIC & 163.37 & 155.85 & 166.54 & 131.91 & 97.81 & 101.49 \\
\hline $\mathrm{BIC}$ & 223.97 & 223.58 & 234.27 & 199.64 & 172.66 & 183.48 \\
\hline
\end{tabular}

Notes: Dummy variables of country and industry are included in the production function.

Numbers in parentheses are standard errors.

We obtain comparable results using the exponential distribution of the inefficiency term.

$* p<.05, * * p<.01, * * * p<.001$ (two-tail).

supplier evaluation, both adjusted by industry mean, as two inputs, and supplier performance as the output. In the second stage, we follow the bootstrap procedure described in Simar and Wilson (2007), a widely used procedure in the field of economics, to overcome the finite sample bias of the naive twostage approach (regression analysis using the DEA efficiency score as dependent variable). This procedure estimates standard errors and confidence intervals by independently drawing pseudo-errors from the truncated normal distribution using a parametric bootstrap procedure (Simar and Wilson 2007). STATA module simarwilson is used for estimation (Badunenko and Tauchmann 2018). Table 6 shows the results of the Simar and Wilson (2007) two-stage estimation approach. The overall results are consistent with prior findings using SFA. Relational norms $(\beta=0.256, p<.001)$ and supplier information sharing
( $\beta=0.298, p<.001)$ are positively associated with supplier development efficiency; buyer information sharing has a negative effect $(\beta=-0.215, p<.001)$ (Table 6, Model 2), which are consistent with the findings from the SFA method. In addition, the interactions are not significant, which are also consistent with the SFA results.

\section{DISCUSSION AND CONCLUSION}

\section{Theoretical contributions}

Existing empirical studies often focus on either identifying best practices or on explaining variations in performance in terms of best practices. Few studies focus on the efficiency of utilizing 
Table 5: Results using two-stage estimation approach (robustness test)

\begin{tabular}{|c|c|c|c|c|}
\hline & Model 1 & Model 2 & Model 3 & Model 4 \\
\hline \multicolumn{5}{|l|}{ Hypothesized factors } \\
\hline Relational norms (RN) & $0.044^{* *}(0.018)$ & & & $-0.012(0.017)$ \\
\hline Buyer information sharing & & $0.012(0.010)$ & & $-0.116^{* * *}(0.015)$ \\
\hline Supplier information sharing & & & $0.064 * * *(0.010)$ & $0.162 * * *(0.016)$ \\
\hline $\mathrm{RN} \times$ Buyer info sharing & & & & $0.068(0.040)$ \\
\hline $\mathrm{RN} \times$ Supplier info sharing & & & & $-0.063(0.039$ \\
\hline \multicolumn{5}{|l|}{ Control variables } \\
\hline Plant size & $-0.003(0.005)$ & $-0.001(0.006)$ & $-0.005(0.005)$ & -0.007 (0.005) \\
\hline Industry dummies & Included & Included & Included & Included \\
\hline$F$-statistics & $3.09 * * *$ & 0.63 & $20.34 * * *$ & $18.64 * * *$ \\
\hline Within $R^{2}$ & 0.024 & 0.005 & 0.141 & 0.314 \\
\hline Between $R^{2}$ & 0.360 & 0.066 & 0.087 & 0.029 \\
\hline Overall $R^{2}$ & 0.014 & 0.001 & 0.087 & 0.274 \\
\hline$N$ & 261 & 261 & 261 & 261 \\
\hline
\end{tabular}

Notes: Dummy variables of industry are included as control variables. Fixed-effect regression with country as the cluster variable.

Numbers in parentheses are standard errors.

Dependent variable: $\ln$ (Efficiency score from SFA).

${ }^{*} p<.05, * * p<.01, * * * p<.001$ (two-tail).

Table 6: Simar and Wilson (2007) two-stage estimation approach with bootstrap standard errors

\begin{tabular}{|c|c|c|}
\hline & Model 1 & Model 2 \\
\hline \multicolumn{3}{|l|}{ Hypothesized factors } \\
\hline Relational norms (RN) & $\begin{array}{c}0.249 * * * \\
(0.053)\end{array}$ & $\begin{array}{c}0.256^{* * *} \\
(0.052)\end{array}$ \\
\hline $\begin{array}{l}\text { Buyer information } \\
\text { sharing }\end{array}$ & $\begin{array}{c}-0.187 * * * \\
(0.047)\end{array}$ & $\begin{array}{l}-0.215^{* * *} \\
(0.047)\end{array}$ \\
\hline $\begin{array}{l}\text { Supplier information } \\
\text { sharing }\end{array}$ & $\begin{array}{c}0.288^{* * *} \\
(0.052)\end{array}$ & $\begin{array}{c}0.298 * * * \\
(0.051)\end{array}$ \\
\hline $\begin{array}{l}\mathrm{RN} \times \text { Buyer info } \\
\text { sharing }\end{array}$ & & $-0.095(0.134)$ \\
\hline $\begin{array}{l}\mathrm{RN} \times \text { Supplier info } \\
\text { sharing }\end{array}$ & & $0.256(0.136)$ \\
\hline \multicolumn{3}{|l|}{ Control variables } \\
\hline Plant size & $-0.023(0.014)$ & $-0.020(0.013)$ \\
\hline Industry dummies & Included & Included \\
\hline Wald $\chi^{2}$ & $86.06^{* * *}$ & $102.33 * * *$ \\
\hline$N$ & 253 & 253 \\
\hline
\end{tabular}

Notes: Dummy variables of industry are included.

Numbers in parentheses are bootstrap standard errors with 2,000 replications.

${ }^{*} p<.05,{ }^{* *} p<.01,{ }^{* * *} p<.001$ (two-tail).

best practices. We demonstrate that relational norms and supplier information sharing can increase a buyer's supplier development efficiency, which prior studies have not yet considered. We also provide a theoretical foundation indicating the reduction in transaction costs is the underlying mechanism for changes in supplier development efficiency.

The finding that information sharing by suppliers is more influential as to supplier development efficiency than information sharing by buyers merits further discussion. Though in theory, information sharing could potentially reduce coordination costs for efficiency gains, existing literature has mixed findings with different attributions and thus calls for future investigations (Hult et al. 2004; Carr and Kaynak 2007; Krause et al. 2007; Blonska et al. 2013). Our study answers this call by separating information sharing into sharing on both sides and finds that in practice, supplier information sharing sends a stronger signal to the buyer regarding the supplier's commitment to the supplier development program. Because supplier development represents a buyer's specific investment in a supplier, the reciprocity of a buyer's goodwill from the supplier is more meaningful than efforts originated by the buyer. Supplier information sharing, in this regard, signals a supplier's willingness to reciprocate a buyer's investment, which further reduces the buyer's transaction risk. In contrast, buyer information sharing may degrade supplier development efficiency when the cost of sharing outweighs its benefit in situations where suppliers experience information overload (Meier 1963). A supplier may also choose to neglect the information provided by buyers to avoid information overload, particularly when the information shared by buyers is self-contradictory. Finally, we did not find consistent interaction effect between relational norms and information sharing on efficiency gains in both SFA and DEA models, which required further research to investigate this issue.

Overall, by differentiating information shared by a supplier versus a buyer, this research casts doubts on the conventional wisdom that information sharing is always helpful (Dyer 1996; 
Takeishi 2001). With much of the existing SD literature either taking a buyer or supplier viewpoint, there is a call for dyadic studies to better our understanding of SD (Krause 1999). This study is one step closer to that call: By differentiating supplier information sharing from buyer information sharing, we consider both views in the same study and find that supplier information sharing is more beneficial to supplier development efficiency than information sharing on a buyer side. Besides, compared to the existing empirical studies that based on samples from one country or a region (e.g., studies by Wagner 2006, 2010, 2011), our sample came from 11 countries across three continents, improving the generalizability of the study findings.

\section{Managerial implications}

Practitioners can benefit from this study as well. The supplier development initiative is subsumed under the broader supply management program with an ultimate goal of improving a buyer's competitive advantages via improved supplier performance. Due to limited human and financial capitals, buyers often struggle with allocating internal resources to supplier development in the hope of improving supplier performance. The study results show that supplier development initiative is a more valuable resource than supplier evaluation for supplier performance. Therefore, we suggest that training and continuous improvement activities with suppliers should be prioritized for managerial attention and resource allocation than building a supplier evaluation system. Another thing that purchasing professionals should be aware of is that contrast to the common belief, buyer information is not a panacea for supplier development efficiency. While buyer information sharing may reduce the bullwhip effect in a supplier, buyers should not expect that their sharing of information with the supplier will increase in supplier development efficiency. Rather, buyer information sharing may reduce supplier development efficiency due to information overload experienced by the supplier. In short, buyers should be aware of the potential downside of sharing information. In contrast, supplier information sharing can increase the efficiency of buyer-initiated supplier development programs. Therefore, buyers should focus on encouraging and designing incentives to motive suppliers to share information with buyers.

The other implication practitioners can take away regards building relational norms with suppliers and supplier information sharing, the two key factors that each enhances supplier development efficiency. Though there lacks a complementary effect between these two, we can still draw inference about the dynamism between them. First, managers should understand that relational norms acts as the lubricant to reduce the wastes (i.e., opportunism, needs of monitoring, or coordination) generated from the transformation process that transforms supplier development initiative and supplier evaluation system to supplier performance. Specifically, increased trust and commitment lead to reduced business partners' desire for secrecy and seeking selfinterest in disguise, motivating information sharing (Modi and Mabert 2007). Moreover, the effect of relational norms alone has a greater magnitude in improving supplier development efficiency than supplier information sharing. Taken together, the results of this study suggest that to improve efficiency when facing limited resources, purchasing and supply chain managers should first invest in building relational norms with their business partners; once a high level of relational norms is established, suppliers would naturally and more likely to discard their guards and share information freely, enhancing efficiency even further.

Overall, we suggest that relational norms and supplier information sharing help explain why some buyers are more efficient at utilizing their supplier development practices to develop their suppliers than others. In sum, if supplier development practices are the hardware for developing suppliers, relational norms and supplier information sharing act as the software that increases the hardware efficiency.

\section{Limitations and future research}

The HPM project is comprehensive and requires a significant amount of commitment from both researchers and industry participants; however, it is not without limitation. The participating firms mainly were mainly recruited through team researchers' personal networks. The measurement scales used in this study are part of the larger HPM project. They were not specifically designed for this study and therefore are confined to the existing survey items. In addition, the research team relied on firm managers' judgments to identify high-performing plants to be included in the HPM project. As the data focus on high-performing plants, the sample is not random. Nonetheless, including only high-performing plants is particularly suitable for this research since the purpose of SFA is to estimate an efficient frontier, and the focus of this study is on proactive and strategic-oriented supplier development, as opposed to reactiveoriented supplier development. An efficient frontier constructed by a group of high-performing plants is more representative and informative than a frontier constructed by a group of randomly selected plants. Another limitation is that the survey data only come from the buyer side. The results that only supplier information sharing has a significant effect may also reflect dyadic differences in buyer-supplier collaborations. Future research is encouraged to collect data from the supplier side to verify the results of this study. Another interesting avenue of future research is to compare our findings with findings from a supplier-initiated context. For programs that are initiated by the suppliers, we suspect that buyer information sharing could be more influential because a supplier would expect reciprocity from the buyer.

In summary, this study establishes a framework and identifies factors for supplier development efficiency. Supplier development consumes significant buyer resources, but the outcomes often vary. We view supplier development from an efficiency perspective and examine factors that help firms use resources more efficiently to achieve better outcomes. Supplier development literature is not short of studies regarding best practices and their effects on performance. Nonetheless, very few studies examine the follow-up question: how to increase the extent of efficiency of using such practices. We hope this research stimulates interest and encourages future researchers to examine managerial practices from an efficiency perspective. 


\section{APPENDIX: MEASUREMENT SCALES}

Alignment method for factor loading with a total of 11 countries (groups)

Table A1: Production function

\begin{tabular}{|c|c|c|c|}
\hline & $\begin{array}{l}\text { Fit function } \\
\text { contribution of } \\
\text { factor loading }\end{array}$ & $\begin{array}{l}\text { Groups with approx. } \\
\text { measurement } \\
\text { invariance }\end{array}$ & $\begin{array}{l}\text { Approximate measurement } \\
\text { invariance (noninvariance) for } \\
\text { groups }\end{array}$ \\
\hline \multicolumn{4}{|l|}{ Supplier development initiative } \\
\hline $\begin{array}{l}\text { We encourage our suppliers to continuously improve } \\
\text { their production processes. }\end{array}$ & -29.47 & 11 & 1234567891011 \\
\hline We offer the necessary training to our suppliers. & -21.83 & 11 & 1234567891011 \\
\hline $\begin{array}{l}\text { We share our vision and supply chain policy with } \\
\text { our key suppliers. }\end{array}$ & -28.68 & 11 & 1234567891011 \\
\hline $\begin{array}{l}\text { As our suppliers strive to improve their processes, } \\
\text { we provide assistance. }\end{array}$ & -36.43 & 11 & 1234567891011 \\
\hline \multicolumn{4}{|l|}{ Supplier evaluation } \\
\hline We have a formal supplier certification program. & -32.54 & 11 & 1234567891011 \\
\hline $\begin{array}{l}\text { Our company has a formal system for tracking the } \\
\text { performance of the suppliers that we deal with. }\end{array}$ & -25.81 & 11 & 1234567891011 \\
\hline $\begin{array}{l}\text { Our plant has a formal system for evaluating and } \\
\text { rewarding suppliers. }\end{array}$ & -29.19 & 11 & 1234567891011 \\
\hline $\begin{array}{l}\text { We assess the performance of our suppliers through } \\
\text { formal evaluation, using established guidelines and } \\
\text { procedures. }\end{array}$ & -25.74 & 11 & 1234567891011 \\
\hline $\begin{array}{l}\text { We provide our suppliers with feedback about the } \\
\text { results of their evaluation. }\end{array}$ & -31.63 & 11 & 1234567891011 \\
\hline \multicolumn{4}{|l|}{ Supplier performance } \\
\hline Fast delivery & -39.04 & 11 & 1234567891011 \\
\hline On-time delivery & -27.47 & 11 & 1234567891011 \\
\hline Product liability & -29.98 & 11 & 1234567891011 \\
\hline Reputation for corporate social responsibility & -33.66 & 11 & 1234567891011 \\
\hline Service level & -31.29 & 11 & 1234567891011 \\
\hline Technical skill & -35.09 & 11 & 1234567891011 \\
\hline Use of sustainability practices & -29.15 & 11 & 1234567891011 \\
\hline $\begin{array}{l}\text { Willingness to adapt processes to meet your } \\
\text { changing needs }\end{array}$ & -32.87 & 11 & 1234567891011 \\
\hline $\begin{array}{l}\text { Willingness to adapt products to meet your changing } \\
\text { needs }\end{array}$ & -35.95 & 11 & 1234567891011 \\
\hline $\begin{array}{l}\text { Willingness to participate in your plant's new } \\
\text { product development }\end{array}$ & -48.78 & 11 & 1234567891011 \\
\hline
\end{tabular}


Table A2: Hypothesized factors in the inefficiency model

\begin{tabular}{|c|c|c|c|}
\hline & $\begin{array}{l}\text { Fit function } \\
\text { contribution of factor } \\
\text { loading }\end{array}$ & $\begin{array}{l}\text { Groups with approx. } \\
\text { measurement invariance }\end{array}$ & $\begin{array}{l}\text { Approximate measurement } \\
\text { invariance (noninvariance) for } \\
\text { groups }\end{array}$ \\
\hline \multicolumn{4}{|l|}{ Relational norms } \\
\hline $\begin{array}{l}\text { When we share our problems with our suppliers, we } \\
\text { know they will respond with understanding. }\end{array}$ & -37.51 & 11 & 1234567891011 \\
\hline $\begin{array}{l}\text { We can count on our suppliers to consider how their } \\
\text { decisions and actions will affect us. }\end{array}$ & -22.23 & 11 & 1234567891011 \\
\hline $\begin{array}{l}\text { We are able to anticipate our suppliers' actions in } \\
\text { specific situations. }\end{array}$ & -38.82 & 11 & 1234567891011 \\
\hline \multicolumn{4}{|c|}{ Buyer information sharing (Our key suppliers have access to the following information about our plant) } \\
\hline Cost information & -55.38 & 11 & 1234567891011 \\
\hline Demand change information & -30.36 & 11 & 1234567891011 \\
\hline Demand forecast information & -33.15 & 10 & $123456789(\mathbf{1 0}) 11$ \\
\hline Plant capability information & -25.04 & 11 & 1234567891011 \\
\hline Inventory information & -26.70 & 11 & 1234567891011 \\
\hline Production capacity information & -30.61 & 11 & 1234567891011 \\
\hline Schedule information & -38.97 & 11 & 1234567891011 \\
\hline \multicolumn{4}{|c|}{ Supplier information sharing (Our plant has access to the following information about our key suppliers) } \\
\hline Cost information & -32.92 & 11 & 1234567891011 \\
\hline Demand change information & -27.69 & 11 & 1234567891011 \\
\hline Demand forecast information & -48.91 & 11 & 1234567891011 \\
\hline Inventory information & -25.83 & 11 & 1234567891011 \\
\hline Production capacity information & -32.58 & 11 & 1234567891011 \\
\hline Productivity information & -36.14 & 11 & 1234567891011 \\
\hline Schedule information & -24.31 & 11 & 1234567891011 \\
\hline
\end{tabular}

\section{Psychometric properties}

Table A3: Production function

\section{Supplier development initiative}

$\mathrm{AVE}=\mathbf{0 . 4 7 5}, \mathrm{CR}=\mathbf{0 . 7 2 8}$, alpha $=\mathbf{0 . 7 1 3}$

We encourage our suppliers to continuously improve their production processes. .658

We offer the necessary training to our suppliers.

We share our vision and supply chain policy with our key suppliers.

As our suppliers strive to improve their processes, we provide assistance.*

\section{Supplier evaluation}

$\mathrm{AVE}=0.594, \mathrm{CR}=0.814$, alpha $=0.844$

We have a formal supplier certification program.

Our company has a formal system for tracking the performance of the suppliers that we deal with. .709

Our plant has a formal system for evaluating and rewarding suppliers.*

We assess the performance of our suppliers through formal evaluation, using established guidelines and procedures.

We provide our suppliers with feedback about the results of their evaluation.*

\section{Supplier performance}

$\mathrm{AVE}=\mathbf{0 . 5 0 8}, \mathrm{CR}=\mathbf{0 . 8 6 1}$, alpha $=0.857$

Fast delivery *

On-time delivery

Product liability

Reputation for corporate social responsibility *

Service level *

Technical skill 
Table A3: (Continued)

Use of sustainability practices

Willingness to adapt processes to meet your changing needs

Willingness to adapt products to meet your changing needs

Willingness to participate in your plant's new product development *

*Excluded due to low factor loadings $(<0.6)$.

Table A4: Hypothesized factors in the inefficiency model

\section{Relational norms}

$\mathrm{AVE}=\mathbf{0 . 5 0 4}, \mathrm{CR}=\mathbf{0 . 7 5 2}$, alpha $=\mathbf{0 . 7 5 5}$

Factor loading

When we share our problems with our suppliers, we know they will respond with understanding. 643

We can count on our suppliers to consider how their decisions and actions will affect us. .705

We are able to anticipate our suppliers' actions in specific situations.

Buyer information sharing (Our key suppliers have access to the following information about our plant)

$\mathrm{AVE}=\mathbf{0 . 5 1 2}, \mathrm{CR}=\mathbf{0 . 8 4 0}$, alpha $=\mathbf{0 . 8 6 5}$

Cost information*

Demand change information

Demand forecast information

Plant capability information*

Inventory information

Production capacity information

Schedule information

Supplier information sharing (Our plant has access to the following information about our key suppliers)

$\mathrm{AVE}=0.626, \mathrm{CR}=0.909$, alpha $=0.914$

Cost information

Demand change information

Demand forecast information

Inventory information

Production capacity information

Productivity information*

Schedule information

\section{REFERENCES}

Aigner, D., Lovell, C.A.K., and Schmidt, P. 1977. "Formulation and Estimation of Stochastic Frontier Production Function Models." Journal of Econometrics 6:21-37. https://doi.org/10. 1016/0304-4076(77)90052-5

Artz, K.W., and Brush, T.H. 2000. "Asset Specificity, Uncertainty and Relational Norms: An Examination of Coordination Costs in Collaborative Strategic Alliances." Journal of Economic Behavior \& Organization 41:337-62.

Asparouhov, T., and Muthén, B. 2014. "Multiple-Group Factor Analysis Alignment." Structural Equation Modeling: A Multidisciplinary Journal 21:495-508.

Badunenko, O., and Tauchmann, H. 2018. Simar and Wilson Two-Stage Efficiency Analysis for Stata. FAU Discussion Papers in Economics, No. 08/2018. Erlangen: FriedrichAlexander-Universität Erlangen-Nürnberg, Institute for Economics.

Banker, R.D., Charnes, A., and Cooper, W.W. 1984. "Some Models for Estimating Technical and Scale Inefficiencies in
Data Envelopment Analysis." Management Science 30:107892. https://doi.org/10.1287/mnsc.30.9.1078

Banker, R.D., and Natarajan, R. 2008. "Evaluating Contextual Variables Affecting Productivity Using Data Envelopment Analysis." Operations Research 56:48-58. https://doi.org/10. 1287/opre.1070.0460

Battese, G.E., and Coelli, T.J. 1995. "A Model for Technical Inefficiency Effects in a Stochastic Frontier Production Function for Panel Data." Empirical Economics 20:325-32. https://doi.org/10.1007/BF01205442

Blonska, A., Storey, C., Rozemeijer, F., Wetzels, M., and de Ruyter, K. 2013. "Decomposing the Effect of Supplier Development on Relationship Benefits: The Role of Relational Capital." Industrial Marketing Management 42:1295-306. https://doi.org/10.1016/j.indmarman.2013.06. 007

Calantone, R., Whipple, J.M., Wang, J.F., Sardashti, H., and Miller, J.W. 2017. "A Primer on Moderated Mediation Analysis: Exploring Logistics Involvement in New Product Development." Journal of Business Logistics 38:151-69. 
Carr, A.S., and Kaynak, H. 2007. "Communication Methods, Information Sharing, Supplier Development and Performance: An Empirical Study of Their Relationships." International Journal of Operations \& Production Management 27:346-70.

Caudill, S.B., and Ford, J.M. 1993. "Biases in Frontier Estimation Due to Heteroscedasticity." Economics Letters 41:17-20. https://doi.org/10.1016/0165-1765(93)90104-K

Caudill, S.B., Ford, J.M., and Gropper, D.M. 1995. "Frontier Estimation and Firm-Specific Inefficiency Measures in the Presence of Heteroscedasticity." Journal of Business \& Economic Statistics 13:105-11.

Chen, C.-M., Delmas, M.A., and Lieberman, M.B. 2015. "Production Frontier Methodologies and Efficiency as a Performance Measure in Strategic Management Research." Strategic Management Journal 36:19-36. https://doi.org/10. 1002/smj.2199

Coelli, T.J., Rao, D.S.P., O'Donnell, C.J., and Battese, G.E. 2005. An Introduction to Efficiency and Productivity Analysis. New York, NY: Springer Science \& Business Media.

Dean, J.W., and Snell, S.A. 1991. "Integrated Manufacturing and Job Design: Moderating Effects of Organizational Inertia." Academy of Management Journal 34:776-804.

De Toni, A., and Nassimbeni, G. 2000. "Just-in-Time Purchasing: An Empirical Study of Operational Practices, Supplier Development and Performance." Omega 28:631-51.

Dutta, S., Narasimhan, O., and Rajiv, S. 2005. "Conceptualizing and Measuring Capabilities: Methodology and Empirical Application." Strategic Management Journal 26:277-85.

Dyer, J.H. 1996. "Does Governance Matter? Keiretsu Alliances and Asset Specificity as Sources of Japanese Competitive Advantage." Organization Science 7:649-66. https://doi.org/ 10.1287/orsc.7.6.649

Dyer, J.H. 1997. "Effective Interfirm Collaboration: How Firms Minimize Transaction Costs and Maximize Transaction Value." Strategic Management Journal 18:535-56.

Dyer, J.H., and Chu, W. 2003. "The Role of Trustworthiness in Reducing Transaction Costs and Improving Performance: Empirical Evidence From the United States, Japan, and Korea." Organization Science 14:57-68. https://doi.org/10. 1287/orsc.14.1.57.12806

Edwards, M.C., and Wirth, R.J. 2009. "Measurement and the Study of Change." Research in Human Development 6:74-96.

Flora, D.B., Curran, P.J., Hussong, A.M., and Edwards, M.C. 2008. "Incorporating Measurement Nonequivalence in a Cross-Study Latent Growth Curve Analysis." Structural Equation Modeling 15:676-704.

Forker, L.B., Ruch, W.A., and Hershauer, J.C. 1999. "Examining Supplier Improvement Efforts From Both Sides." The Journal of Supply Chain Management 35:40-50. https://d oi.org/10.1111/j.1745-493X.1999.tb00061.x

Fornell, C., and Larcker, D.F. 1981. "Evaluating Structural Equation Models With Unobservable Variables and Measurement Error." Journal of Marketing Research 18:3950.

Frazier, G.L., Spekman, R.E., and O’Neal, C.R. 1988. "Just-inTime Exchange Relationships in Industrial Markets." Journal of Marketing 52(4):52-67. https://doi.org/10.2307/1251633
Fugate, B.S., Mentzer, J.T., and Stank, T.P. 2010. "Logistics Performance: Efficiency, Effectiveness, and Differentiation." Journal of Business Logistics 31:43-62.

Gefen, D., and Straub, D. 2005. "A Practical Guide to Factorial Validity Using PLS-GRAPH: Tutorial and Annotated Example." Communications of AIS 2005:91-109.

Green, A., and Mayes, D. 1991. "Technical Inefficiency in Manufacturing Industries." The Economic Journal 101:52338.

Greene, W.H. 2008. The Econometric Approach to Efficiency Analysis. Oxford, UK: Oxford University Press.

Grover, V., and Malhotra, M.K. 2003. "Transaction Cost Framework in Operations and Supply Chain Management Research: Theory and Measurement." Journal of Operations Management 21:457-73. https://doi.org/10.1016/S0272-6963 (03)00040-8.

Hadri, K. 1999. "Estimation of a Doubly Heteroscedastic Stochastic Frontier Cost Function." Journal of Business \& Economic Statistics 17:359-63.

Hahn, C.K., Watts, C.A., and Kim, K.Y. 1990. "The Supplier Development Program: A Conceptual Model." Journal of Purchasing and Materials Management 26:2-7.

Hair, J.F., Black, W.C., Babin, B.J., Anderson, R.E., and Tatjam, R.L. 2006. Multivariate Data Analysis. 7th ed. Upper Saddle River, NJ: Pearson Education International.

Hartley, J.L., and Choi, T.Y. 1996. "Supplier Development: Customers as a Catalyst of Process Change." Business Horizons 39:37-44.

Heide, J.B., and John, G. 1988. "The Role of Dependence Balancing in Safeguarding Transaction-Specific Assets in Conventional Channel." Journal of Marketing 52:20-35. https://doi.org/10.2307/1251683

Heide, J.B., and John, G. 1992. "Do Norms Matter in Marketing Relationships?" Journal of Marketing 56:32-44. https://doi. org/10.2307/1252040

Henseler, J., Ringle, C.M., and Sinkovics, R.R. 2009. "The Use of Partial Least Squares Path Modeling in International Marketing." In New Challenges to International Marketing, edited by R.R. Sinkovics and P.N. Ghauri, 277-319. Emerald Group Publishing Limited.

Hu, L., and Bentler, P.M. 1999. "Cutoff Criteria for Fit Indexes in Covariance Structure Analysis: Conventional Criteria Versus New Alternatives." Structural Equation Modeling: A Multidisciplinary Journal 6:1-55.

Hu, L.-T., and Bentler, P.M. 1995. "Evaluating Model Fit." In Structural Equation Modeling: Concepts, Issues, and Applications, edited by R.H. Hoyle, 76-99. Thousands Oaks, CA: Sage.

Hult, G.T.M., Ketchen, D.J. Jr., and Slater, S.F. 2004. "Information Processing, Knowledge Development, and Strategic Supply Chain Performance." Academy of Management Journal 47:241-53.

Humphreys, P.K., Li, W.L., and Chan, L.Y. 2004. "The Impact of Supplier Development on Buyer-Supplier Performance." Omega 32:131-43. https://doi.org/10.1016/j.omega.2003.09. 016

Johnson, A.L., and Kuosmanen, T. 2012. "One-Stage and TwoStage DEA Estimation of the Effects of Contextual 
Variables." European Journal of Operational Research 220:559-70. https://doi.org/10.1016/j.ejor.2012.01.023

Johnston, D.A., McCutcheon, D.M., Stuart, F.I., and Kerwood, H. 2004. "Effects of Supplier Trust on Performance of Cooperative Supplier Relationships." Journal of Operations Management 22:23-38. https://doi.org/10.1016/j.jom.2003.12. 001

Kembro, J., and Näslund, D. 2014. "Information Sharing in Supply Chains, Myth or Reality? A Critical Analysis of Empirical Literature." International Journal of Physical Distribution \& Logistics Management 44:179-200.

Krause, D.R. 1997. "Supplier Development: Current Practices and Outcomes." International Journal of Purchasing and Materials Management 33:12-19. https://doi.org/10.1111/j. 1745-493X.1997.tb00287.x

Krause, D.R. 1999. “The Antecedents of Buying Firms' Efforts to Improve Suppliers." Journal of Operations Management 17:205-24. https://doi.org/10.1016/S0272-6963(98)00038-2

Krause, D.R., and Ellram, L.M. 1997a. "Critical Elements of Supplier Development: The Buying-Firm Perspective." European Journal of Purchasing \& Supply Management 3:21-31. https://doi.org/10.1016/S0969-7012(96)00003-2

Krause, D.R., and Ellram, L.M. 1997b. "Success Factors in Supplier Development." International Journal of Physical Distribution \& Logistics Management 27:39-52.

Krause, D.R., Handfield, R.B., and Scannell, T.V. 1998. "An Empirical Investigation of Supplier Development: Reactive and Strategic Processes." Journal of Operations Management 17:39-58. https://doi.org/10.1016/S0272-6963 (98)00030-8

Krause, D.R., Handfield, R.B., and Tyler, B.B. 2007. "The Relationships Between Supplier Development, Commitment, Social Capital Accumulation and Performance Improvement." Journal of Operations Management 25:528-45. https://doi. org/10.1016/j.jom.2006.05.007

Krause, D.R., Scannell, T.V., and Calantone, R.J. 2000. "A Structural Analysis of the Effectiveness of Buying Firms' Strategies to Improve Supplier Performance." Decision Sciences 31:33-55. https://doi.org/10.1111/j.1540-5915.2000. tb00923.x

Kumar, N., Scheer, L.K., and Steenkamp, J.-B.E. 1995. "The Effects of Supplier Fairness on Vulnerable Resellers." Journal of Marketing Research 32(1):54-65.

Lascelles, D.M., and Dale, B.G. 1989. "The Buyer-Supplier Relationship in Total Quality Management." Journal of Purchasing and Materials Management 25:10-19.

Leenders, M.R. 1966. "Supplier Development." Journal of Purchasing 2:47-62.

Li, S., and Lin, B. 2006. "Accessing Information Sharing and Information Quality in Supply Chain Management." Decision Support Systems 42:1641-56. https://doi.org/10.1016/j.dss. 2006.02.011

Li, W., Humphreys, P.K., Yeung, A.C.L., and Cheng, T.C.E. 2012. "The Impact of Supplier Development on Buyer Competitive Advantage: A Path Analytic Model." International Journal of Production Economics 135:353-66. https://doi.org/10.1016/j.ijpe.2011.06.019

Lieberman, M.B., and Dhawan, R. 2005. "Assessing the Resource Base of Japanese and U.S. Auto Producers: A
Stochastic Frontier Production Function Approach." Management Science 51:1060-75. https://doi.org/10.1287/ mnsc. 1050.0416

Lin, F., Huang, S., and Lin, S. 2002. "Effects of Information Sharing on Supply Chain Performance in Electronic Commerce." IEEE Transactions on Engineering Management 49:258-68. https://doi.org/10.1109/TEM.2002.803388

McEvily, B., and Marcus, A. 2005. "Embedded Ties and the Acquisition of Competitive Capabilities." Strategic Management Journal 26:1033-55.

Meeusen, W., and van Den Broeck, J. 1977. "Efficiency Estimation From Cobb-Douglas Production Functions With Composed Error." International Economic Review 18(2):43544. https://doi.org/10.2307/2525757

Meier, R.L. 1963. "Communications Overload: Proposals From the Study of a University Library." Administrative Science Quarterly 7(4):521-44. https://doi.org/10.2307/2390963

Min, S., Mentzer, J.T., and Ladd, R.T. 2007. "A Market Orientation in Supply Chain Management." Journal of the Academy of Marketing Science 35:507-22. https://doi.org/10. 1007/s11747-007-0020-x

Modi, S.B., and Mabert, V.A. 2007. "Supplier Development: Improving Supplier Performance Through Knowledge Transfer." Journal of Operations Management 25:42-64. https://doi.org/10.1016/j.jom.2006.02.001

Monczka, R.M., Petersen, K.J., Handfield, R.B., and Ragatz, G.L. 1998. "Success Factors in Strategic Supplier Alliances: The Buying Company Perspective." Decision Sciences 29:553-77. https://doi.org/10.1111/j.1540-5915.1998.tb01354.x

Nagati, H., and Rebolledo, C. 2013. "Supplier Development Efforts: The Suppliers' Point of View." Industrial Marketing Management 42:180-88.

Narasimhan, R., Jayaram, J., and Carter, J.R. 2009. "An Empirical Examination of the Underlying Dimensions of Purchasing Competence." Production and Operations Management 10:1-15. https://doi.org/10.1111/j.1937-5956. 2001.tb00064.x

Narasimhan, R., Talluri, S., and Méndez, D. 2001. "Supplier Evaluation and Rationalization via Data Envelopment Analysis: An Empirical Examination." The Journal of Supply Chain Management 37:10. https://doi.org/10.1111/j.1745493X.2001.tb00103.X

Nyaga, G.N., Whipple, J.M., and Lynch, D.F. 2010. "Examining Supply Chain Relationships: Do Buyer and Supplier Perspectives on Collaborative Relationships Differ?" Journal of Operations Management 28:101-14.

Paulraj, A., Lado, A.A., and Chen, I.J. 2008. "InterOrganizational Communication as a Relational Competency: Antecedents and Performance Outcomes in Collaborative Buyer-Supplier Relationships." Journal of Operations Management 26:45-64. https://doi.org/10.1016/j.jom.2007.04. 001

Podsakoff, P.M., MacKenzie, S.B., Lee, J.-Y., and Podsakoff, N.P. 2003. "Common Method Biases in Behavioral Research: A Critical Review of the Literature and Recommended Remedies." The Journal of Applied Psychology 88:879-903. https://doi.org/10.1037/0021-9010.88.5.879

Reed, F.M., and Walsh, K. 2002. "Enhancing Technological Capability Through Supplier Development: A Study of the 
UK Aerospace Industry." IEEE Transactions on Engineering Management 49:231-42.

Rindfleisch, A., and Heide, J.B. 1997. "Transaction Cost Analysis: Past, Present, and Future Applications." Journal of Marketing 61:30. https://doi.org/10.2307/1252085

Schroeder, R.G., and Flynn, B.B. 2001. High Performance Manufacturing: Global Perspectives. New York, NY: John Wiley \& Sons.

Shah, R., and Goldstein, S.M. 2006. "Use of Structural Equation Modeling in Operations Management Research: Looking Back and Forward." Journal of Operations Management 24:148-69.

Simar, L., and Wilson, P.W. 2007. "Estimation and Inference in Two-Stage, Semi-Parametric Models of Production Processes." Journal of Econometrics 136:31-64.

Simon, H.A. 1955. "A Behavioral Model of Rational Choice." The Quarterly Journal of Economics 69(1):99-118. https://d oi.org/10.2307/1884852

Spekman, R.E. 1988. "Strategic Supplier Selection: Understanding Long-Term Buyer Relationships." Business Horizons 31:7581. https://doi.org/10.1016/0007-6813(88)90072-9

StataCorp. 2015. "Stata Statistical Software: Release 14." College Station, TX: StataCorp LP.

Stevenson, R.E. 1980. "Likelihood Functions for Generalized Stochastic Frontier Estimation." Journal of Econometrics 13:57-66.

Swink, M., Narasimhan, R., and Kim, S.W. 2005. "Manufacturing Practices and Strategy Integration: Effects on Cost Efficiency, Flexibility, and Market-Based Performance." Decision Sciences 36:427-57. https://doi.org/10.1111/j.15405414.2005.00079.x

Takeishi, A. 2001. "Bridging Inter- and Intra-Firm Boundaries: Management of Supplier Involvement in Automobile Product Development." Strategic Management Journal 22:403-33. https://doi.org/10.1002/smj.164

Tourangeau, R., Singer, E., and Presser, S. 2003. "Context Effects in Attitude Surveys: Effects on Remote Items and Impact on Predictive Validity." Sociological Methods \& Research 31:486-513. https://doi.org/10.1177/00491241032 51950

Turkulainen, V., Kauppi, K., and Nermes, E. 2017. "Institutional Explanations: Missing Link in Operations Management? Insights on Supplier Integration." International Journal of Operations \& Production Management 37:1117-40. https://d oi.org/10.1108/IJOPM-10-2015-0608

Wagner, S.M. 2006. "Supplier Development Practices: An Exploratory Study." European Journal of Marketing 40:55471. https://doi.org/10.1108/03090560610657831

Wagner, S.M. 2010. "Indirect and Direct Supplier Development: Performance Implications of Individual and Combined Effects." IEEE Transactions on Engineering Management 57:536-46.

Wagner, S.M. 2011. "Supplier Development and the Relationship Life-Cycle." International Journal of Production
Economics 129:277-83. https://doi.org/10.1016/j.ijpe.2010.10. 020

Watts, C.A., and Hahn, C.K. 1993. "Supplier Development Programs: An Empirical Analysis." International Journal of Purchasing and Materials Management 29:10-17. https://doi. org/10.1111/j.1745-493X.1993.tb00002.x

Williamson, O. 1985. The Economic Institutions of Capitalism. New York: Free Press.

Williamson, O.E. 1981. "The Economics of Organization: The Transaction Cost Approach." American Journal of Sociology 87:548-77.

Williamson, O.E. 1991. "Comparative Economic Organization: The Analysis of Discrete Structural Alternatives." Administrative Science Quarterly 36:269-96. https://doi.org/ $10.2307 / 2393356$

Yu, Z., Yan, H., and Cheng, T.C.E. 2013. "Benefits of Information Sharing With Supply Chain Partnerships." Industrial Management \& Data Systems 101:114-21. https://d oi.org/10.1108/02635570110386625

Zhang, D., Linderman, K., and Schroeder, R.G. 2012. "The Moderating Role of Contextual Factors on Quality Management Practices." Journal of Operations Management 30:12-23. https://doi.org/10.1016/j.jom.2011.05.001

Zhou, H., and Benton, W. 2007. "Supply Chain Practice and Information Sharing." Journal of Operations Management 25:1348-65.

\section{SHORT BIOGRAPHIES}

Hung-Chung Su (PhD University of Minnesota) is an Assistant Professor of Operations Management at the University of Michigan-Dearborn. His research interests include quality management and operational systems. His academic works can be found in premier journals such as the Journal of Operations Management, Decision Sciences, Journal of Supply Chain Management, and Journal of Business Logistics.

Yi-Su Chen ( $\mathrm{PhD}$ University of Minnesota) is an Associate Professor of Operations Management at the University of Michigan-Dearborn. Her research interest area is supply chain management; some of her research are featured in top journals such as the Journal of Operations Management. Prior to returning to academia, Dr. Chen worked for around 10 years with Accenture, Unilever, Hewlett Packard, and Agilent.

Ta-Wei (Daniel) Kao (PhD State University of New York at Buffalo) is an Assistant Professor of Operations Management at the University of Michigan-Dearborn, College of Business. Dr. Kao's research interests include supply chain management, social network analysis, and econometric analysis. His academic works have appeared in the European Journal of Operational Research, Decision Support Systems, and Computers in Human Behavior. 